(C) В.К. Малькова

\title{
ЛИСТОВКИ, НАКЛЕЙКИ И ТАБЛИЧКИ КАК ФОРМЫ РЕГУЛИРОВАНИЯ МАССОВОГО ПОВЕДЕНИЯ В СОВРЕМЕННОМ РОССИЙСКОМ МЕГАПОЛИСЕ*
}

\begin{abstract}
В статье рассматривается одна из форм регулирования человеческого поведения в современном большом городе. Автор обращается к общественному регулированию и, в частности, к одному из необычных его ресурсов - листовкам, наклейкам и табличкам, встречающимся в городском пространстве. Многочисленные примеры таких регуляторов, зафиксированных автором в 2020 году в российской столице, показывают, как эти небольшие носители человеческого опьта участвуют в процессе сочиализации населения, в самоуправлении и самоорганизации социума. Указания, советы, рекомендации, предупреждения и ограничения (запреты), содержашиеся в этих информационных источниках, проанализированы, типологизированы и описаны как одна из мальх форм организаџии современного общества, находящегося в условиях демократических преобразований и набирающей силу гражданской активности. Рассматривая сочиально-культурные функции этого регулятора, автор показывает его значение для жизни обычных людей. Это - передача человеческого опьта по горизонтали и вертикали, внимание и забота сограждан о своей повседневной жизни, а порой - и некоторое их принуждение к выполнению определенных правил, к разумному использованию общего городского пространства. Это также формирование общей на данный момент системы иенностей, положительных стандартов и установок, моделей поведения в данном соииуме.
\end{abstract}

Ключевые слова: регулирование поведения, современный город, листовки, наклейки и таблички, указания, советы, рекомендации, сочуиально-культурные функции регулятора

Ссылка при цитировании: Малькова B.К. Листовки, наклейки и таблички как формы регулирования массового поведения в современном российском мегаполисе // Вестник антропологии, 2021. № 4. С. 251-268.

\section{Введение}

В начальный период самоизоляции во время пандемии 2020 года, когда выходить из дома все же изредка приходилось, мы обратили внимание на одно из интересных общественных явлений, которому в обычное время чаще всего не придается особого зна-

Малькова Вера Константиновна - д.и.н., главный научный сотрудник, Институт этнологии и антропологии РАН (119991 Москва, Ленинский просп., 32a). Эл. почта: veramalk@mail.ru

*Работа написана в рамках темы НИР №7 ИЭА РАН «Современные нации, нациестроительство и российская идентичность» 
чения. Это увеличение в городском пространстве количества небольших и разнообразных надписей, листовок, наклеек и табличек. Обычно эти небольшие листки бумаги с зафиксированными советами, указаниями, рекомендациями, а иногда и с запретами располагают на стенах и на дверях зданий, в транспорте, в учреждениях, на уличных столбах и оградах. По нашим наблюдениям, в последние несколько лет количество и разнообразие этих небольших надписей пополнилось в российской столице не только листовками и наклейками, но и другими малыми формами - табличками, стикерами, флаерами и стало более заметным. Одна из причин - необходимость предупреждать людей о серьезной опасности в связи с пандемией Ковид-19. Но не только. Это еще и один из способов регулирования и корректировки действий и направлений огромных людских потоков, сосредоточенных в большом городе, способ оптимизации в городском пространстве массового повседневного поведения населения.

Понятие «регулирование» используют в разных сферах жизни, хотя оно и не всегда употребляется однозначно. Представители технических профессий рассматривают этот процесс как «отлаживание системы». Исследователи общественных процессов подчеркивают этим термином «целенаправленное воздействие общества и государства, их структур на социально-политическую жизнь, на действия и поведение людей, в соответствии с ценностями и нормами каждого общества и с использованием системы социального контроля» (Мокшин 2000). Социальное регулирование понимается также и как «руководство движением, направлением, действиями, отношениями», как «приведение в порядок, упорядочение механизма, деятельности» и т. п. Кроме того, словари уточняют, что регулирование - это «совокупность предписаний, исходящих от органа власти или управления и имеющих целью внести известный порядок в ту или другую сферу жизни». И это одна из технологий «целенаправленного управляющего воздействия, ориентированного на поддержание равновесия в управляемом объекте и на его развитие посредством введения в него регуляторов (норм, правил, целей, связей)» (Большой словарь). Таким образом, организация и координация жизни и деятельности любых социокультурных сообществ, куда гармонично вписываются и эти малые формы, очень многозначная и непростая задача. Об этом хорошо знают не только руководители стран, областей, городов и предприятий, но и главы обычных семей в любом доме.

Активное преобразование реальности, происходящее в мире и в России, касается всех сторон жизни и деятельности человека - политической, социальной, экономической, культурной и прочей. Оно отражается на жизни различных городов и стран, их социокультурной сфере, включая обычную повседневную жизнь и человеческие взаимоотношения. Усиливается демократизация общественных отношений, растет гражданская активность у представителей разных групп населения, появляются и развиваются народные инициативы, формируются зачатки гражданского общества, выступающего за свои права. Мотивация этих изменений у россиян кроется в стремлении улучшить свою жизнь, жизнь своих семей и близких, своих городов, своей страны. Во всем этом точечно и осторожно используется политический и социальный опыт других стран, применяются известные социально-культурные технологии и инновации.

Известно, что с далекого прошлого в каждом большом сообществе, осуществляется как государственное регулирование общественной жизни, так и общественное или социальное. Что касается государственного регулирования, оно осуществляется обычно с помощью законов, закрепленных в конституциях, в гражданских и уго- 
ловных кодексах, в указах и постановлениях правительств и министерств, в региональных законах и актах, с помощью судебной системы и т.д. Государство что-то запрещает или разрешает своим гражданам, а затем с разной степенью внимания с помощью своего чиновничьего аппарата контролирует их выполнение. в этом ему помогают многие государственные и общественные механизмы и рычаги управления, в том числе и разнообразные информационные службы.

Так, журналисты, судя по медийным сообщениям, уже давно приучили граждан к информированию о таких формах государственного регулирования общественной жизни как: «российские власти делают все, чтобы поднять рождаемость в стране», «заботятся о процветании своего народа», «восстанавливают занятость населения» и т.п. Подобные фразы знакомы всем, кто получает информацию через медийные каналы. Сегодняшнему населению хорошо знакомы и такие мобилизационные выражения чиновников как: «нужно настроить механизмы управления», «нужны усилия», «необходимо контролировать» и т.П., транслируемые практически безадресно с совещаний различных уровней. в медийных сообщениях уже стало привычным упоминать и о других действиях властей, связанных с регулированием жизни россиян на глобальном уровне: «необходимо проводить балансирование бюджета», «необходимо выходить на траекторию устойчивого роста» и т.п. Все это - довольно абстрактные формы регулирования и управления (цитаты взяты из российской прессы), которые далеко не всегда приводят к успеху. Кроме упомянутых выше, в качестве регуляторов общественной жизни и в больших, и в малых сообществах нередко используются и такие механизмы как почти незаметное создание в обществе определенного социально-психологического климата, как целенаправленное отвлечение общественного внимания от конкретных проблем, сплочение или расслабление сообщества, актуализация или забвение у его членов некоторых фактов, традиций, символов и стандартов, а также персонажей. Используются и слухи, предрассудки, стереотипы...

Однако повседневная жизнь населения, как известно, регулируется не только государством, но еще и самим обществом, которое порой также использует приведенные выше методы. в качестве регулятора может служить общественный договор (например, носить маски и перчатки в период пандемии) и некоторые другие, не всегда официально зафиксированные требования, процедуры, правила, стандарты. А порой - и просто указания, советы, решения отдельных людей или групп (учителей, медиков, старейшин). Таким образом с помощью определенных социальных технологий и механизмов в сообществе устанавливается и на какой-то период сохраняется необходимый и одобряемый большинством общественный порядок и общественное согласие.

В разных сообществах порядки и нормы общественного поведения далеко не всегда бывают одинаковыми, о чем свидетельствуют как наблюдения этнографов и других ученых (Мартынова 2004; Бгажноков 1999; 1978; Гафурова 2005), так и известные народные поговорки: «У нас так не принято /принято»; «В чужой монастырь со своим уставом не ходят». И хотя нормы и правила поведения сохраняются и оберегаются в обществе как традиции, они все же не остаются статичными. Технический прогресс, а иногда и внезапные катаклизмы (как пандемия), массовые миграции и другое, способствуют изменению локальных или общепринятых моделей поведения людей. При несоблюдении правил определенной группой граждан, а порой даже одним индивидом, общественный порядок и в самом деле может быть нарушен, что приведет к «сбою системы», к массовым отклонениям от общеприня- 
тых норм, к конфликтам, групповым выступлениям и беспорядкам, даже погромам и убийствам, что в настоящее время мы с тревогой наблюдаем в ряде стран. в таких случаях и государство, и общество с разной степенью эффективности стараются приводить в действие определенные регулировочные механизмы или корректирующие меры. При этом используются как государственные, так и социальные методы регулирования массового поведения, включая и «отклонения». Исследователи этих процессов подчеркивают, что в настоящее время в России с учетом постоянных реформ в государственном устройстве страны, функция государственного регулирования становится преобладающей и первостепенной (Наумов 2008).

Соглашаясь в целом с этим утверждением, нельзя не обратить внимание на появление и широкое распространение в городских сообществах разных форм социального (общественного) регулирования, в т.ч. негосударственных социальных регуляторов. в данной работе на примере московского городского социума, который условно можно считать самоорганизующейся социокультурной системой, мы обратимся к одной из форм негосударственных регуляторов, все шире распространяющихся в городском пространстве. С их помощью человеку в разных формах подсказывается - что хорошо, полезно, удобно и необходимо сделать или наоборот - плохо, вредно, опасно и что вообще нельзя делать в определенных ситуациях. Именно поэтому можно говорить не только о регулировании, но о саморегулировании общества, как одной из форм общественных процессов, которые фиксируются и изучаются в разных обществах и на разных этапах (Бобнева 1978; Пригожин 1995).

Существует ряд определений процесса саморегулирования, который рассматривается, в частности, как «легитимное регулирование сфер деятельности самими агентами, с четко регламентированным участием государства». Этот процесс определяется и как самостоятельная и инициативная деятельность, а также как «контроль за соблюдением требований указанных стандартов и правил» (Внедрение).

Некоторые исследователи называют саморегулирование (например, в аудите) перспективным направлением развития, которое соответствует формированию гражданского общества и демократизации управления. И в самом деле, процесс саморегулирования в нашей стране пока находится в начальной стадии развития и связан он в основном с бизнесом и с рыночными отношениями. Хотя, как показывают наши наблюдения, сферы этого процесса гораздо шире. Люди или «объекты взаимодействия» с помощью самостоятельных и инициативных советов, указаний и пожеланий направляются «инициаторами» или «субъектами взаимодействия» на использование более эффективных методов и способов своей деятельности в социальном пространстве.

$* * *$

Обращаясь к проблеме регулирования и саморегулирования массового поведения населения, предварительно остановимся на общей картине современного городского пространства. Пространство современного мегаполиса - огромная и сложная социокультурная система и одно из важных мест для регулирования людских потоков. в основу большинства уличных социальных регуляторов положена определенная информация, позволяющая с ее помощью и в наши дни явно или незаметно направлять и корректировать человеческое передвижение в общественном пространстве - управлять, регулировать, манипулировать людскими потоками. 
Городская территория где-то стихийно, а в других местах - согласно градостроительным планам, поделена на улицы, площади, парки, дворы, дороги. Определенная разметка общественного пространства и не только в городах существовала, как известно, с древнейших времен, например, в форме межевых и пограничных столбов, в форме дорожных указателей, природных ориентиров. Дороги предназначены для транспорта, обочины, тротуары и переходы - для пешеходов. Так сложилось исторически. в огромном городе человеку нелегко ориентироваться в незнакомом пространстве. Даже сегодня, далеко не каждый горожанин имеет под рукой навигатор, схему или карту города, района. Пешеходам и водителям требуются ориентиры, дорожные указатели, маркеры пространства, необходимы подсказки, советы и прямые указания - как быстрее и удобнее проехать, как безопасно перейти улицу, найти нужное здание. в XXI веке, когда автомобилей в больших городах стало огромное количество, регулирование транспортных потоков превратилось в совсем не простую задачу. Конечно, уже давно на автомобильных дорогах и площадях, вместе с установлением правил дорожного движения появляется и разметка, а также стоят знаки (информационные, запрещающие, предупреждающие, разрешающие, предписывающие, знаки сервиса, указатели скорости и др.), стоят светофоры, висят различные информационные щиты и прочее. На некоторых остановках общественного транспорта для ориентации людей сегодня закреплены карты-схемы, показывающие место, где человек находится, и ближайшие окрестности. На фасадах зданий висят таблички с названиями улиц, площадей, что также помогает человеку ориентироваться в незнакомом месте.

Кроме навигаторских форм во многих крупных городах в настоящее время используются и другие регуляторы общественного поведения, например, рекламные. Реклама - не только «двигатель торговли», как говорили в прежние времена, но и регулятор массового поведения людей, двигатель некоторых людских потоков и их действий. в настоящее время, как известно, большое количество различных рекламных конструкций украшают или наоборот уродуют облик городского пространства. Они разнообразны и по форме, и по содержанию, как и их не всегда понятные названия: вывески, информационные, рекламные и выставочные стенды и указатели, световые панели, ситилайты, панель-кронштейны, штендеры, шелфтокеры, воблеры, лайтбоксы, крышные установки, рекламные щзиты, навесы, домовые знаки, ростовые фигуры, козырьки, маркизы, таблички, номерки... Практически все эти формы встречаются в современной Москве. Всеми этими городскими регуляторами руководят, как правило, городские власти. Но вместе с ними некоторые правила поведения устанавливает и само общество, и даже порой - отдельные люди.

Оставляя в стороне огромный массив разнообразной городской рекламы, которую мы уже частично рассматривали (Малькова 2014), обратимся еще к одному регулятору - к «народным» надписям-листовкам, мелким вывескам, указателям и другим небольшим формам в московском городском пространстве. Листовки, таблички, флаеры и другие письменно-иллюстративные малые формы, очень близко соприкасаются с социальной рекламой. Эти надпи- 
си вместе с другими малыми формами также можно рассматривать как «вид некоммерческой рекламы, направленной на изменение моделей общественного поведения и привлечения внимания к проблемам социума» (Социальная). И хотя в Законе РФ «О рекламе» подчеркивается, что «настоящий Федеральный закон не распространяется на вывески и указатели, не содержащие сведений рекламного характера, на объявления физических лиц или юридических лиц, не связанные с осуществлением предпринимательской деятельности» (Ф3 2006), это также один из рычагов и механизмов, помогающих обществу решать «социально-общественные проблемы и привлекать к ним внимание общества» (Ф3 2016).

Объектом и источником нашего исследования и рассмотрения механизмов регулирования поведения людей в современном общественном пространстве будут материалы наблюдений и коллекция надписей, зафиксированных нами в 2020 году на улицах современной российской столицы. Это простые надписи с московских улиц, встречающиеся всем в транспорте, в учреждениях и организациях, приклеенные к стене, к стеклу или к дверям, на транспорте, на улице, на стенах домов. Это небольшие листовки (а также флаеры и стикеры), информационные таблички или штампованные надписи на тротуapax, на камне или на асфальте с указаниями и рекомендациями, советами и предупреждениями, пожеланиями и запретами. Порой они напоминают и о некоторых правилах поведения... Именно для горожан и приезжих, для отдельных людей или небольших групп пешеходов, пассажиров общественного транспорта, для покупателей магазинов и рынков, пациентов поликлиник, посетителей различных заведений предназначены, например, сообщения: Соблюдайте меры профилактики // Держите дистанциию 1,5м // Берегите свое здоровье // При выходе не забывайте свои вещци // Чаще мойте руки // У ворот машины не ставить // Проход запрещзен... и многие другие. Эти несиловые формы регулирования социального поведения, которые иногда выглядят как легкое «принуждение», помогают явно или скрыто корректировать его, направлять и перенаправлять большие и малые людские потоки, расширять их или сужать, сокращать или усиливать, тем самым регулируя действия этих потоков.

Таким образом, само общество, основываясь на многовековом опыте человеческого общения, с помощью небольших листочков, наклеек и табличек с простыми житейскими напоминаниями и советами ориентирует, регулирует и направляет поведение людей. Эти «малые регулирующие формы» многообразны, а порой даже противоречивы и поэтому нуждаются в определенной систематизации и изучении не только как один из заметных штрихов в современной городской жизни, но и как фактор самоорганизации, саморегулирования городского социума.

Листо́вка - одна из малых форм регулирования общественного поведения. Для носителей разнообразных надписей, появляющихся в современном городском пространстве, пока нет единого объединяющего их термина, поэтому и другие малые формы мы будем условно называть «листовками». в классическом виде это, как из- 
вестно - лист бумаги с текстом, иногда с иллюстрациями и, как указывается в ряде словарей, это форма агитационно-политической или информационной литературы (Что такое листовка). К такому восприятию этого небольшого листочка бумаги с информацией, а нередко и с призывами, многие привыкли по литературе и по кинофильмам еще с революционно-военных времен XX века. Но и сегодняшние словари все еще подчеркивают, что листовки применяются в революционной деятельности, политических кампаниях, во время военных действий. Однако времена меняются, а вместе с ними меняются многие предметы и их функции, что также уже отражено в некоторых современных словарях: «Листовка- это один из распространенных, эффективных, а также недорогих видов рекламной продукции. С их помощью можно не только привлекать новых клиентов, но и информировать о новых событиях» / Листовка - это важный информационный носитель рекламного типа для потребителей, а для компаний - один из самых выгодных и удобных способов рекламирования товаров и услуг / Листовка - это самый распространенный, доступный вид печатной рекламы. Это лист бумаги с текстом, который часто используют для массового информирования населения» (Виды листовок). Именно последнее определение в большей степени подходит к рассматриваемому объекту.

Было бы неплохо понаблюдать и зафиксировать эффективность этих небольших социальных регуляторов, понять, насколько люди выполняют советы, требования и рекомендации, предлагаемые им в листовках и табличках. Конечно, некоторую эффективность этих небольших указателей и мы замечали в отдельных случаях в транспорте, на уличных переходах, в магазинах и других местах. Наблюдения показывают, что большинство людей безропотно выполняют необходимые советы, указания, просьбы и предписания. Порой это происходит без напоминаний, по уже давно выработанной привычке, автоматически, в силу опыта и воспитания. Бывает и игнорирование советов, например, люди не надевают маски, проходят в неположенных местах и без очереди, не оплачивают проезд, оставляют автомобили на газонах...Заметим, что восприятие советов и указаний, норм и стандартов поведения зависит как от самого человека, так и от конкретного окружения в данном месте. Люди видят камеры слежения, смотрят друг на друга и следуют примерам поведения соседей, причем, как позитивно, так и негативно. Поэтому на некоторых листовках размещают рисунки-карикатуры с изображением персонажей, отказывающихся выполнить рекомендацию и попадающих впросак или на штраф.


Рис. 1. Примеры советов, рекомендащий и указаний в современном городском пространстве (фото автора). 
Однако на данной стадии нам представляется важным рассмотреть не столько восприятие людьми навязываемых им правил, советов и рекомендаций, а сами эти правила, их содержание и их прикладную и бытовую ценность, а также многие другие характеристики, порождаемые современной городской действительностью и особенно - тревожной атмосферой 2020 года.

\section{Формы регулирования городского социума}

Поведение человека в обществе, как показывают ученые, организовывалось и корректировалось разными методами практически всегда (Бутовская, Тишков 2018). Переходя к рассмотрению современной действительности, остановимся ненадолго на прежнем отечественном опыте массового регулирования поведения населения. Не заглядывая вглубь российской истории, хотя и это крайне интересно, напомним, что, например, в Советском Союзе также использовались разные советы и рекомендации, оформлявшиеся в том числе в рамках «наглядной агитации». И как оказалось, это до сих пор практически в той же форме сохраняется в Республике Беларусь (Изготовление). в советское время на улицах городов висели большие панно или плакаты с призывами: «Храните деньги в сберегательной кассе!» или «Летайте самолетами Аэрофлота!». Надписи призывали людей не мусорить и соблюдать личную гигиену. С самого детства в детском саду и в школе детям рекомендовали с чистить зубы и делать зарядку, расти смелыми, сильными и трудолюбивыми. С помощью плакатов, песен, стихов, с помощью художественной литературы, прессы и кинофильмов людей призывали хорошо трудиться, направляли на подвиги, на защиту родины... Многие из этих советов актуальны до сих пор.

Плакаты, лозунги, другие наглядные материалы призывали людей не только к труду, но и к «правильному» поведению дома и на улице, к строительству новой жизни в стране, к защите родины от врагов. Многие эти рекомендации провозглашались не только от имени государства, но и от имени общества. И огромную роль в их создании и распространении играли представители творческих профессий - поэты и писатели, музыканты, художники и артисты, получавшие заказы от властей. Таким образом, с помощью нехитрых механизмов наглядной агитации, с помощью работников культуры, журналистов и кинематографа, а также при участии общественных активистов, партийных и общественных организаций власти контролировали и организовывали поведение и настроение масс, что далеко не всегда проходило успешно. Долгое время, и не только в советский период, это делалось довольно интенсивно и поощрялось общественной моралью и разными средствами пропаганды.

Выше уже упоминалось, что основными темами для наглядной агитации в советское время были в том числе и бытовые советы (не мусорить, не ходить по газонам), рекомендации о гигиене (следить за своим здоровьем), о принятых в обществе морально-нравственных нормах (не лодырничать, не пьянствовать, сохранять свою семью), призывы к трудовым успехам, к просвещению («Учиться, учиться и еще раз учиться»). Советским людям внушали как «правильно» себя вести - быть скромным, не гнаться за карьерой, не хитрить и не обманывать ... Общество решительно осуждало лодырей, лентяев, тунеядцев, пьяниц и дебоширов. Их лишали премий, «песочили» на собраниях. Юмористы и сатирики рассказывали о нарушителях со сцены, их высмеивали в фельетонах, в кинофильмах, в карикатурах и на «досках позора». Вместе 
с такими мерами наказания широко использовались и другие формы общественного регулирования поведения - частушки, басни, пословицы и поговорки. И наоборот, достойных ожидали награды в виде поощрений - премий, путевок в дома отдыха, портретов на досках почета. Воспитательно-пропагандистский пафос государства и общества, включающий идеологические призывы и лозунги, были направлены в то время и на прославление страны («Страна моя, Москва моя - ты самая любимая!»), коммунистической партии и ее лидеров (Да здравствует...! Слава...!). Большинство этих советов и рекомендаций от имени общества были адресованы отдельному человеку, а лозунги и призывы - всем советским людям, порой - и зарубежному пролетариату.

В наше время к прежним рекомендациям и советам что-то добавилось, например, некоторые правила поведения в обществе, что-то ушло в историю (например, обращения к пролетариям всех стран или прославление одной партии), но многое и осталось. И это свидетельствует о непреходящих ценностях общественной жизни, которые важно фиксировать. Если внимательно посмотреть вокруг, то и сегодня мы увидим в современном городском пространстве множество различной информации, бытовых и других советов, подсказывающих людям как рационально и удобно жить, нормально чувствовать себя в обществе. Эта информация даже на первый взгляд разнообразна. Плакаты, которые раньше вывешивались на некоторых фасадах домов, в наши дни заменились огромными рекламными щитами, нередко светящимися. Улицы городов теперь пестрят большими и малыми формами и надписями, указывающими, ориентирующими, советующими, приглашающими или запрещающими... Рассматривая множество советов и указаний, зафиксированных на улицах современной российской столицы, мы выделили несколько основных видов информации, которую городской житель получает из этого источника.

Если рассматривать только малые формы - листовки, флаеры и стикеры, то прежде всего привлекает внимание их внешний вид. Чаще всего на небольшом листке или табличке можно видеть только надпись. Но в последнее время на них стали появляться и иллюстрации. Это хорошо видно в предупреждениях и инструкциях о здоровье, в частности - о ковиде. Текст надписей в листовках обычно краткий, простой и понятный, состоит из небольших фраз. Чаще всего текст печатный, при нынешнем повсеместном распространении компьютеров и принтеров это стало общепринятым. Реже такие советы и рекомендации написаны от руки. Запреты и некоторые ключевые слова чаще всего выделяются крупным черным шрифтом. в настоящее время в стране и особенно в городах появились специальные службы, помогающие создавать и распространять разные форматы надписей. Так, в интернете встречаются сообщения о том, что в городе работают службы срочной печати массовой рекламы, службы «профессиональной оклейки транспорта», офисов, витрин. Рекламодатели и спонсоры предлагают помощь в создании текстов листовок, завлекают своих клиентов тем, что их «воодушевляющие рекламные тексты помогут выжить в условиях жесткой конкуренции и обеспечить успешный маркетинг» (ReklamaPlanet; Социальная реклама).

Авторами небольших посланий, по нашим наблюдениям, может быть практически любой человек - муниципальный служащий, руководитель учреждения или любой так называемый «активный гражданин». Иногда это конкретный человек, отвечающий за порядок в данном месте, например, дворник, уборщица: Не бросайте мусор мимо урны!! / Не лейте горячую воду в раковину... Это может быть и водитель 



Рис. 2. Примеры обращений к населению во время пандемии 2020, (фото автора). маршрутки, автобуса: Не забывайте оплачивать свой проезд! На листке бумаги или на табличке может стоять и не всегда понятная подпись «Администрация»: Служебный вход / Служебная автостоянка / Машины не ставить... Но автором может быть и обычный неравнодушный прохожий: Ocmoрожно, там яма! ... в любом случае, автор своим посланием проявил заботу о неизвестных ему людях, которые могут оказаться в этом месте (или о себе), предупредил их о возможных последствиях или препятствиях, на-

помнил им о лучшем способе их действий, подсказал как, когда и что лучше сделать.

Адресат, потребитель или объект послания, целевая аудитория для таких письменных советов, как показал анализ, не всегда четкая и определенная, чаще случайная и неорганизованная. Она зависит как от места расположения надписи (улица, учреждение, транспорт, двор), так и от направленности сообщения. Иногда обращение направлено на всех, то есть, на неопределенный круг лиц: Носите медицинские маски и перчатки /Делайте зарядку по утрам... Иногда указание адресовано только одному человеку - прохожему, клиенту, покупателю, пассажиру: Приложите карту / Поверните ручку, дверь и откроется... Или группе людей: Больше 4-х человек в лифт не заходить... Иногда надписи все же бывают и четко направленными, например, для отдельных групп: для женщин, для пожилых, для инвалидов, для детей... Места для пожильх ... Места для родителей с детьми ... Не выбегай на дорогу! ... Покупатель всегда прав! ... Берегите себя и своих близких! ...

Форма обращения к «адресату» или язык обращения также разнообразен. Это рекомендация / запрет / предупреждение// навязывание... Однако каждое обращение предполагает понимание, сознательность человека, его послушание или устрашение.

Общественная сфера, к которой можно отнести надпись, далеко не всегда четко определяется. Тем не менее, среди советов можно выделить: здоровье, гигиену, правила движения, нормы общежития, удобство для окружающих, практичность, прагматизм...

Время и длительность действия листовок, надписей или самих советов варьируется: от «постоянно или временно» до «сиюминутно или навсегда». «Долгоигра- 

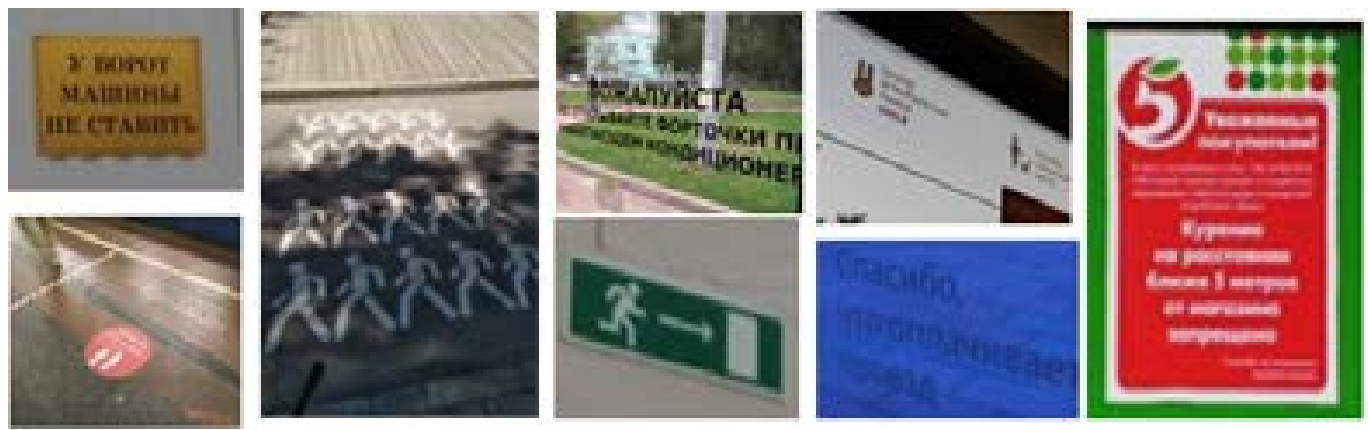

Рис.3. Примеры рекомендащий на улице и в транспорте (фото автора).

ющие» листовки на бумажных носителях, конечно, не остаются всегда свежими, надписи выгорают и стираются, если их не обновляют. Флаеры, напечатанные на пленке, более долговечны и красочны. Но все же такие надписи недолговременны и чаще всего относятся к настоящему моменту (Наденьте маску // Оплатите проезд... в настоящем времени информация может быть и временной: Уила на перерыв, скоро буду... Авторы могут направить «адресата - читателя» и в будущее: Принимаем посетителей только по понедельникам... Иногда речь идет и о длительных действиях: Соблюдайте правила гигиены / Берегите спички от детей/Спасибо, что уступаете место... Среди советов встречаются и сиюминутные инструкции или рекомендации о срочном действии: Приложите карту / толкай дверь / Оплатите свой проезд.../ Входите, у нас интересно... / в случае пожара звоните ...

Место действия. Интересен и такой нюанс как локальность или глобальность предлагаемой информации. в надписях не всегда указано пространство, на которое распространяется рекомендуемое действие - улица, двор, транспорт, магазин, кафе, поликлиники, учреждение культуры. Потребитель сам должен догадаться как использовать данное указание - только в этом месте или везде, локально или глобально. Тем не менее, в ряде надписей все же имеются некоторые понятные всем рекомендации здесь, там, везде. Например, здесь: У нас не курят / Внимание! Объект охраняется / Bbхход на посадку / Огнеопасно! Газ! ... Там: Остановка за углом / С высокой температурой - в следуюшую дверь... Везде: Переходя дорогу, будьте внимательны ... Некоторые надписи не имеют ни места, ни времени, их можно назвать неопределенными. Но они также важны для регулирования поведения: Пешеходам: Переходите дорогу только в указанных местах. Водителям: Водитель, будь внимателен на дороге! ...

Интересна степень строгости рекомендации и обязательность ее исполнения. Этот момент в листовках также неоднороден и сочетает в себе как строгий запрет, так и возможные компромиссы. Степень обязательности выполнения совета и здесь зависит от самого реципиента, условного «читателя». Поэтому надписи можно разделить на те, которые рассчитаны на собственное сознательное и самостоятельное решение, и те, которые предполагают обязательное выполнение рекомендаций или запретов. Приведем примеры: Строгий запрет: Внимание! На территории запрещено курить / Проход закрыт / Вход с собаками запрещен! / Не бросать жвачку на пол! ... Нельзя, но допустимо, совет: Придерживайтесь левой стороны/ Водитель, не превышай скорость! ... Не запрет, но просьба: Просьба не садиться на это место... Информация: Разрешается бесплатно взять / бесплатно пройти ... Предупреждение: За бесплатный проезд- итраф ... 


$$
* * *
$$

На представленные материалы можно взглянуть и с другого ракурса, например, выделить разные жанры сообщений - простая информация, призывы, советы, рекомендации и другое. Некоторые надписи могут относиться сразу к двум или трем группам, поэтому предлагаемая типология в данном случае довольно условна.

\section{Информация, сообщения, инструкции:}

- Профилактика пожаров сохраняет жизни

- Весы на кассе. Удивительно удобно

- Открыто. Тяни на себя / Толкай

- Не толкать! Калитка открывается автоматически!

- Срочный выкуп

\section{Призывы:}

- Рассчитывайтесь банковской картой

- Поможем ребенку!

- Звоните нам...

\section{Советы, рекомендации:}

- Не откладывайте важные дела на завтра!

- Читайте книгу - источник знания

- Не экономим! Качество важнее /

- Тише едешь - дальше будешь

- Любишь кататься, люби и денежки платить...

Совет- благодарность:

- Спасибо, что убрали за собой

- Спасибо, что оплачиваете проезд

- Спасибо, что уступаете места

- Спасибо, что выбросили мусор в урну

Предупреждение:

- Штраф за безбилетный проезд 1000 рублей

- За использование чужих социальных карт - штраф 2500 рублей

- Внимание! Вас копируют ваши дети!

- Огнеопасно! Газ!

- Выезд спецтранспорта

\section{Запрет:}

- Курение на расстоянии ближе 5 метров от магазина запрещено

- Только для служебных машин

- $\quad$ Не стой под стрелой

- За буйки не заплывать!

- Купаться запрещено

- У ворот машины не ставить

- $\quad$ Проход запрещен, посторонним вход запрещен

- Парковка автомобилей запрещена круглосуточно

\section{Инструкция:}

- Приложите карту 


\section{Просьба:}

- Пожалуйста не открывайте форточки при работающем кондиционере

- Пожалуйста не занимайте это место

\section{Подсказка, напоминание:}

- Более свободный вагон

- При выходе не забывайте свои вещи

- Книга - лучший подарок

- В случае пожара звоните по номеру

\section{Предупреждающие иллюстрации:}

- Человек в инвалидной коляске

- Предупреждающий жест, ладонь

- Идущий по переходу человек

- Стрелка - вправо, влево, вниз, вверх

- Человек с собачкой - перечеркнуто

\section{Шутка:}

- Бери сейчас, плати потом.

- Тише едешь, лучше сохранишься.

- Набери код, дверь и откроется.

- Не обижай маленьких! (Надпись на автомобиле ОКА).

В тревожные месяцы 2020 года нельзя было не обратить внимание на надписи, связанные с коронавирусом. Это также - лаконичная информация, советы и рекомендации о личной гигиене, о соблюдении масочного режима и о социальной дистанции. Это повторяющиеся на дверях зданий, при входе в различные торговые заведения рисунки вируса, человека в маске, перечеркнутые изображения собачек. И хотя они также, как и надписи, мало информативны и носят в основном профилактический характер, они раз за разом напоминают прохожим о возможных негативных последствиях и реальной опасности заражения, о необходимости беречься. Особенностью надписей, связанных с коронавирусом, является строгий, порой приказной стиль. При этом в подобных листовках заметно не хватает просветительской информации. Приведем некоторые примеры:

- Что нужно знать о коронавирусе

- Соблюдайте меры профилактики!

- Берегите свое здоровье!

- Носите защитные маски и перчатки!

- Реже прикасайтесь к лицу!

- Мой руки перед едой. Помни про гигиену!

- Держите дистанцию, не садитесь здесь!

- Соблюдайте дистанцию!

- Без маски и перчаток не входить!

- Внимание! Соблюдайте дистанцию!

- Держите дистанцию 1,5м!

- Проезд в городском транспорте только в масках и перчатках!

- Люди в масках (рисунок).

- Берегите свое здоровье. 


\section{Социокультурные функции листовок}

Может встать вопрос: какую социальную роль играют эти надписи-листовки-таблички в жизни и миропонимании современных городских жителей? Рассматривая общественные функции этого носителя указаний, советов и рекомендаций, заметим, что определенные правила, обычаи, нормы всегда необходимы обществу для его нормального существования и развития. Зафиксированные в том числе и в небольших надписях-листовках подобные надписи-рекомендации практически незаметно выполняют такие социокультурные функции как регулирующую, коммуникативную, информационную, воспитательную, просветительскую и другие. Эти указания и советы, а иногда и запреты, важны в частности для обеспечения общественного порядка и для безопасности людей в городском пространстве, в трудовом коллективе, в семье. Наряду с другими общественными механизмами, они способствуют формированию общей на данный момент системы ценностей, положительных стандартов и установок в общественных отношениях, сообщают людям о принятых в данном социуме определенных нормах, полезных и удобных моделях поведения.

Распространяемые правила, советы, рекомендации и запреты, основанные на длительном человеческом опыте, направлены также и на передачу этого опыта по горизонтали и вертикали. Через незамысловатую информацию передаются советы и наставления о том, что удобнее и безопаснее для человека и окружающих делать так, а не этак. С помощью этих небольших регуляторов поведение людей в определенных пределах также контролируется и от отклонений (Отклоняющееся).

Кроме того, через социальное регулирование, в частности, через транслирование в общественное пространство организующей и корректирующей информации происходит коммуникация между людьми, стандартизация их привычек и действий. Членов сообщества и таким образом направляют и обучают делать общественное пространство более удобным не только для себя, но и для других, заботиться не только о себе, о своем бытии, о здоровье, о внешнем виде, о своем духовном состоянии, но также о своих близких. Их (нас) призывают проявлять внимание к знакомым и незнакомым людям, у них (у нас) формируют чувство долга и уважения к другим. Обычные советы, напоминания и предупреждения в разных местах помогают членам сообщества незаметно интегрироваться в социум и адаптироваться в нем. И все это направлено не только на обеспечение общественного порядка и согласия, но и на социальный контроль, на поддержание групповой солидарности, на единство и сплочение членов сообщества, знающих и выполняющих общие стандарты и правила, и на выделение в нем «своих».

В качестве недалекого примера можно напомнить бурные 90-е годы, когда огромные массы инокультурных мигрантов практически одновременно нахлынули в российскую столицу. Их поведение, привычки и образ жизни заметно отличались от того, к чему привыкли москвичи. Нужно было время, огромное терпение горожан и властей для того, чтобы люди приспособились, привыкли друг к другу, адаптировались в новом пространстве. И для этого было необходимо не только доброжелательное отношение принимающего сообщества, но и разъяснения, инструкции, рекомендации приезжим. И они были - напоминания, советы, памятки, правила и нормы поведения для мигрантов (Памятки по; в помощь мигранту), что в значительной мере помогло смягчить в столице возникшую заметную напряженность в межнациональном общении. 
Некоторые аналитики, изучающие значение общественного регулирования в бизнесе, отмечают его необходимость и для равенства участников экономических отношений, для основ демократической конкуренции, а также для прав и свобод граждан (Принципы). Соглашаясь и с этим дополнением, можно фиксировать, что с помощью направленного регулирования общественного поведения осуществляется профилактика, а иногда и устранение возможных сбоев в системе общепринятых человеческих отношений. Кроме того, распространение в городском пространстве определенных правил и норм поведения, простых житейских советов и рекомендаций способствует также формированию, сохранению и развитию местных традиций, правил, привычек... И в конечном счете все это положительно влияет на формирование местной и групповой идентичности. Эти небольшие носители человеческого опыта участвуют таким образом в процессе социализации населения, в процессах самоуправления и саморегулирования социума.

Социальные функции, выполняемые этими листовками, многочисленны. Конечно, порой советы, рекомендации или запреты замечаются людьми ненадолго и через некоторое время они могут легко забыться в круговерти событий и дел. Но в определенные моменты, в похожих ситуациях они могут у человека актуализироваться.

\section{Выводы}

Рассмотрев одну из форм общественного саморегулирования поведения своих сограждан, можно видеть, как само общество заботится о спокойствии, удобстве и о рациональном, осмысленном их поведении в разных ситуациях. Впервые представленные в данной работе и рассмотренные нами примеры разнообразных надписей, листовок и табличек, распространенных в современном городском пространстве, еще раз демонстрируют обширное социокультурное многообразие современного мира и различные механизмы его организации. Даже такие малые информационные рычажки как незаметные на первый взгляд надписи и листовки с советами, рекомендациями или указаниями способны участвовать в общественных процессах, помогать организовывать поведение и жизнь отдельного человека и больших групп людей, утверждать и обеспечивать групповую солидарность жителей мегаполиса. Авторы небольших листовочных посланий и обращений - обычные горожане, принимающие и таким образом участие в организации жизни своего сообщества. Они проявляют заботу о своем городе, о его жителях, а порой - и некоторое принуждение сограждан к выполнению определенных правил, к разумному использованию общего городского пространства. Как показывают наблюдения, в городском пространстве (в данном случае - в российской столице) довольно свободно распространяются «активными гражданами» простые и повседневные бытовые указания о принятых в сообществе правилах и нормах поведения. И вместе с тем, свободная саморегуляция общества и в настоящий период происходит в сочетании с определенными самоограничениями и самоцензурой.

Среди разных типов общественных регуляторов поведения мы попытались увидеть особенности обращений и призывов их инициаторов к согражданам, определить их общественный потенциал в локальном сообществе. в частности, обнаружилось и было показано немалое значение социальной (гражданской) активности авторов листовок для передвижения людей в городском пространстве с минимизацией возможных рисков, подчеркнута ответственность членов городского сообщества при напоминаниях 
его членам о соблюдении личной и общественной гигиены, особенно в условиях пандемии, показана необходимость соблюдения норм вежливости и культуры общения в современном обществе... Одновременно в этих маленьких регуляторах были выявлены профилактическая и контролирующая составляющие, предупреждающие людей о нежелательных отклонениях от общепринятых в городе стандартов. Важно отметить, что в современном полиэтничном и поликонфессиональном московском пространстве, несмотря на огромное разнообразие московского населения, на этих небольших информационных листочках полностью отсутствуют любые упоминания социальных и национальных признаков. Информация относится к людям любых социальных групп, любых национальностей, и выделяется порой лишь гендерная принадлежность. То есть, московское сообщество, озабоченное идеей сохранения городского спокойствия, несмотря на его сложную этносоциальную городскую структуру, и здесь проявляет толерантность, не разделяет в этом массы людей на отдельные группы. Все это положительно влияет на формирование местной и групповой идентичности.

Таким образом, листовки - эти небольшие носители человеческого опыта участвуют в процессе социализации населения, в формировании групповой солидарности членов сообщества, в самоуправлении и саморегулировании социума. При этом и государственное, и общественное регулирование происходит одновременно, в тандеме, что не вызывает противоречий и приносит пользу и спокойствие мегаполису.

\section{Источники и материалы}

Большой словарь - Большой словарь по социологии. www.rusword.com.ua.

В помощь мигранту - в помощь мигранту. Памятка (общая). www.migimo.ru $r a z d e l / 189$ (Дата обращения: 18.11.20) и др.

Виды листовок - Виды листовок для рекламы. www.uton.ru>articles/vidy-listovok (Дата обращения: 29.10.20)

Внедрение - Внедрение стандартов. Госконтроль за соблюдением требований. / lektsii.net/3171040.html (Дата обращения: 30.10.20)

Листовка - Листовка. https://dic.academic.ru>dic.nsf/ruwiki/ (дата обращения: 29.10.20).

Изготовление - Изготовление стендов наглядной агитации в Беларуси. https://by.all. biz>izgotovlenie-stendov-naglyadnoj (дата обращения: 29.10.20).

Мокшин 2000 - Мокшин В.К.' Словарь-справочник по социологии. Учебно-методическое пособие. Архангельск: Изд-во Арханг. гос. мед. акад. 2000 г. https://docviewer.yandex.ru/ (дата обращения 17.09.2020).

Отклоняющееся - Отклоняющееся поведение. https://cf2.ppt-online.org/files2/ (дата обращения: 18.11.20).

Памятки по - Памятки по вопросам миграции для иностранцев. Мвд.рф (дата обращения: 18.11.22).

Принципы - Принципы предпринимательского права. https:/cloud.prezentacii. org/18/11/100571/images/ (дата обращения: 18.11.22).

Социальная реклама - Социальная реклама. https://marketing.spb.ru>lib-comm/ (дата обращения: 29.10.20)

Ф3 2006 - Федеральный Закон «О рекламе» от 13.03.2006 № 38-Ф3. https://marketing/ sotsialnaya-reklamaConsultant.ru>document/cons_doc_LAW_58968/ (дата обращения: 29.10.20)

Ф3 2016 - Федеральный Закон «О саморегулируемых организациях» (в ред. Федеральных законов от 22.07.2008 N 148-Ф3, от 03.07.2016 N 360-Ф3, от 03.08.2018 № 340-Ф3). https:// Consultant.ru>document/cons_doc_LAW_72967 (дата обращения: 29.10.20)

Что такое - Что такое листовка. /BigPicture.ru> (дата обращения: 29.10.20) 
Словари и - Словари и энциклопедии на Академике. https:/dic.academic.ru>dic.nsf/socio/ (дата обращения: 17.09.2020)

Право в - Право в системе социальных норм. http://900igr.net/datas/pravo/Pravo-RossijskojFederatsii/ (дата обращения: 18.11.20)

Яндекс. Карты - Яндекс. Карты. http://maps.yandex.ru〉MyPlenka (дата обращения: 18.11.20)

ReklamaPlanet - Бизнес-журнал ReklamaPlanet. http://reklamaplanet.ru〉 (дата обращения: 29.04.21)

\section{Научная литература}

Бгажноков Б.Х. Коммуникативное поведение и культура // Советская этнография, 1978. № 5. C. 3-17.

Бгажноков Б. Х. Адыгская этика. Нальчик. Издательство Эль-Фа. 1999. 96 с.

Бобнева М.И. Социальные нормы и регуляция поведения. М.: Наука. 1978. 312 с.

Бутовская М.Л., Тишков В.А. Феномен индоктринации / Медийная индоктринация: антропологические исследования / Отв. ред. В.К. Малькова, В.А. Тишков. М.: ИЭА РАН. 2018. C.14-23.

Гафурова Л. В. Менеджмент социально-культурной деятельности в процессе самоорганизации сельского населения. Автореферат канд. пед. наук. Москва. 2005 Доступ: http://naukapedagogika.com/pedagogika-13-00-05.

Малькова В.К. Новое этнопространство современной Москвы // Исследования по прикладной и неотложной этнологии № 235. М.: ИЭА РАН, 2014. 107 с.

Мартынова М.Ю. Мир традиций и межкультурное общение. в помощь школьному учителю. М.: РУДН, 2004. 348 с.

Мартынова М.Ю. Традиции и инновации в соционормативной культуре. М.: ИЭА РАН. 2008. Наумов. С.Ю. Система государственного управления. Издательство Форум. 2008. 304 с. www.bookol.ru (дата обращения: 29.10.20).

Пригожин А.И. Современная социология организаций. М. 1995, 296 с.

Malkova, Vera $K$.

\section{Leaflets, Stickers, and Signs as a Means of Mass Behavior Regulation in the Modern Russian Metropolis}

\section{DOI: $10.33876 / 2311-0546 / 2021-4 / 251-268$}

The article examines one of the forms of regulation of human behavior in a modern big city. The author focuses on an unusual means of public regulation - leaflets, stickers, and signs, often found in the urban space. Numerous examples of such regulators, recorded by the author in 2020 in the Russian capital, show how these small media can participate in the population's socialization and self-government, and self-regulation of society. The instructions, advice, recommendations, warnings, and restrictions (prohibitions) contained in these sources were analyzed, classified, and described as a form of organization of a modern society going through democratic transformations and reinforcement of civic activity. The author highlights the importance of these media for the socio-cultural life of ordinary people. They transfer human experience vertically and horizontally, reflect the attention and care of fellow citizens about their daily life, and sometimes call for complying with certain rules and for the reasonable use of the common urban space. They also take part in forming a common system of values, positive standards, and attitudes, behavioral models in a given society.

Keywords: regulation of behavior, modern city, leaflets, stickers and signs, instructions, advice, recommendations, socio-cultural functions of the media 
For Citation: Malkova, V.K. 2021. Leaflets, Stickers, and Signs as a Means of Mass Behavior Regulation in the Modern Russian Metropolis. Herald of Anthropology (Vestnik Antropologii) 4: 251-268.

Author Info: Malkova, Vera K. - Dr. of Hist., Leading Researcher, Institute of Ethnology and Anthropology RAS (Moscow, Russia). E-mail: veramalk@mail.ru

Funding: The research is published as part of the Research Plan of the Institute of Ethnology and Anthropology RAS

\section{References}

Bgazhnokov, B.Kh. 1978. Kommunikativnoe povedenie i kultura [Communicative behavior and culture]. Sovetskaya ehtnografiya 5: 3-17.

Bgazhnokov, B. Kh. 1999. Adygskaya ehtika [Adyghe ethics]. Nalchik: Izdatelstvo Ehl-Fa.

Bobneva, M.I. 1978. Socialnye normy i regulyaciya povedeniya [Social norms and regulation of behavior]. Moscow: Nauka.

Butovskaya, M.L., Tishkov, V.A. 2018. Fenomen indoktrinacii [The phenomenon of indoctrination]. In Malkova, V.K., V.A.Tishkov (ed). Medijnaya indoktrinaciya: antropologicheskie issledovaniya [Media indoctrination: anthropological research], 14-23. Moscow: Institute of Ethnology and Anthropology Russian Academy of Science.

Gafurova, L.V. 2005. Menedzhment socialno-kulturnoj deyatelnosti v processe samoorganizacii selskogo naseleniya [Management of socio-cultural activities in the process of selforganization of the rural population]. $\mathrm{PhD}$ astract, Moscow. /http://nauka-pedagogika.com/ pedagogika-13-00-05/.

Malkova, V.K. Novoe ehtnoprostranstvo sovremennoj Moskvy. Issledovaniya po prikladnoj i neotlozhnoj ehtnologii [New ethno-space of modern Moscow. Research on applied and urgent ethnology], vol. 235. Moscow: Institute of Ethnology and anthropology Russian Academy of Science.

Martynova, M.Yu. 2004. Mir tradicij i mezhkulturnoe obshchenie. Vpomoshch shkolnomu uchitelyu [The world of traditions and intercultural communication]. Moscow: Peoples Friendship University of Russia.

Martynova, M.Yu. 2008. Tradicii i innovacii v socionormativnoj kulture [Traditions and innovations in socionormative culture]. Moscow: Institute of Ethnology and anthropology Russian Academy of Science.

Naumov, S.Yu. 2008. Sistema gosudarstvennogo upravleniya [System of state administration]. Moscow: Izdatelstvo Forum.

Prigozhin, A.I. 1995. Sovremennaya sociologiya organizacij [Modern sociology of organizations]. Moscow. 